\title{
The incidence of insomnia among employed and unemployed individuals*
}

\author{
Weronika Wolińska $\bowtie$ \\ Pomeranian Medical University in Szczecin Poland, Department of Humanities in Medicine, gen. Dezyderego Chłapowskiego 11, 70-103 Szczecin, Poland
}

ORCID: 0000-0002-3358-8280

$\triangle$ weronika.wolinska@pum.edu.pl

\begin{abstract}
Introduction: Insomnia is a complex disorder and requires knowledge of the subjective feelings of the patient. The incidence of insomnia varies depending on the classification and definition used in the study, and usually oscillates between $4-48 \%$. Insomnia lowers quality of life (QoL), which translates into poorer functioning at social and professional levels.

The aim of this study was to determine the incidence of insomnia among employed and unemployed individuals with regard to their sociodemographic and socioeconomic data, to analyze the relationship between insomnia, depressive symptoms and chronic diseases, and to assess how insomnia affects QoL.

Materials and methods: This survey-based study included 597 people. The following questionnaires were used: the Athens Insomnia Scale (AIS), Beck's Depression Inventory (BDI), the Short Form 36 Health Survey (SF-36), and a self-developed questionnaire.

Results: Insomnia was found in $17.75 \%$ ( $n=106$; $p \leq 0.001$ ) of respondents. There was a statistically significant relationship
\end{abstract}

\section{INTRODUCTION}

Insomnia is a complex disorder and requires knowledge of the subjective feelings of the patient [1]. Diagnosis is made on the basis of diagnostic criteria, including standard criteria for the classification of mental disorders offered by the Diagnostic and Statistical Manual of Mental Disorders (DSMV) published by the American Psychiatric Association (APA). It states that insomnia can be diagnosed if the patient has difficulty falling and staying asleep, wakes up too early and cannot fall asleep again. Such problems should occur at least 3 times per week and last for at least 3 months [2]. Chronic insomnia may have numerous adverse effects. The consequences of sleep deprivation have been divided into immediate and long-term ones [3]. Immediate effects are lower cognitive functions, a feeling of fatigue and drowsiness, reduced immunity, susceptibility to mental diseases, and lower quality of life (QoL) $[4,5,6]$. Long-term effects are decreased work efficiency and absence from work [7]. The incidence of insomnia varies depending on the classification and definition applied, and usually oscillates between 4-48\% [7]. It is also determined by sociodemographic and economic factors $[8,9]$. Studies show between insomnia and sex $(\mathrm{p}=0.006)$. Insomnia was more common in women $(20.83 \% ; \mathrm{n}=75)$, people over 56 years of age $(27.08 \% ; n=26 ; p \leq 0.001)$, and those unemployed $(26.37 \%$; $\mathrm{n}=53 ; \mathrm{p} \leq 0.001)$. A statistically significant relationship was demonstrated between depression and insomnia assessed by the AIS $(\mathrm{p} \leq 0.001)$.

Conclusions: 1 . Insomnia was more common in unemployed individuals. 2. Insomnia was more common in those with hypertension, irrespective of their employment status. Therefore, primary care physicians should use the AIS as part of screening among chronically ill patients. 3. Insomnia was accompanied by depressive symptoms in all groups analyzed in this study, irrespective of their employment status. 4. Insomnia is a serious public and mental health problem. The AIS should be used as part of workers' periodic health examinations, since ignoring the problem of insomnia decreases QoL.

Keywords: insomnia; sleep disorders; employment; work; quality of life.

that insomnia is more prevalent with older age, female sex, obesity, and a low level of education $[10,11,12,13,14,15]$. The risk of insomnia is also exacerbated by the presence of chronic diseases [16], such as hypertension, since the cardiovascular system is related to the circadian rhythm $[17,18]$, and diabetes $[19,20]$. The most common mental problem accompanying insomnia is depression [21]. Insomnia and poor quality of sleep belong to risk factors for depression, and redouble the probability of falling ill [22]. Both insomnia can cause depression, and reversely depression can lead to insomnia. It is indicated that in people suffering from depression, each depressive episode is preceded by sleep problems [22, 23]. Insomnia lowers QoL, and consequently impairs functioning at social and professional levels [24].

Insomnia disrupts the circadian rhythm, so shift-work poses a risk of sleep disorders, among them insomnia, but its consequences can also be observed in the psychological sphere, including a fivefold greater risk of depression [25]. According to Virtanen et al., the type of employment contract can substantially contribute to the risk to insomnia. A decline in somatic and mental health is observed especially in people employed for a limited period of time. The uncertainty of employment

* The concise version of the PhD thesis approved by the Council of the Faculty of Health Sciences, Pomeranian Medical University in Szczecin. Thesis supervisor: dr hab. n. zdr. Bożena Mroczek, prof. PUM. Original version consists of 212 pages, 56 figures, 54 tables, 298 references. 
involves stress, which negatively affects the quality and quantity of sleep [26, 27, 28].

The aim of this study was to determine the incidence of insomnia among employed and unemployed individuals with regard to their sociodemographic and socioeconomic data; to analyze the relationship between insomnia, depressive symptoms and chronic diseases; and to assess how insomnia affects QoL.

\section{MATERIAL AND METHODS}

The criteria for inclusion in the study was an age between 18-65 years, place of residence in West Pomeranian Voivodeship, and participation in the study on a voluntary basis. Participants were selected based on quota sampling by sex, place of residence, and employment status. The study involved 597 individuals, comprising 360 (60.3\%) women and 237 (39.7\%) men. Three hundred ninety six (66.33\%) of the participants were employed, and 201 (33.67\%) were unemployed. The largest groupings of respondents were those aged up to 25 years ( $n=171 ; 28.63 \%)$, those with 3 rd-level education ( $n=315$; $52.76 \%$ ), and residents of cities with a population of over 100,000 ( $\mathrm{n}=239 ; 58.58 \%$ ) - Table 1 . The largest occupational group ( $n=129 ; 34.49 \%$ ) were specialists (teachers, physicians, physiotherapists, engineers etc.). In the whole study sample, 201 respondents (33.67\%) were shift workers, the majority of respondents were contract workers $(n=277 ; 69.95 \%)$ - Table 2 .
The study was performed using the Athens Insomnia Scale (AIS), Beck's Depression Inventory (BDI), the Short Form 36 Health Survey (SF-36) version 2, and the author's questionnaire concerning sociodemographic and economic data. The AIS consists of eight insomnia-related questions, each answered on a four-point scale and scored $0-3$. The AIS total scores are interpreted as follows: $<5$ points - no insomnia, $6-10$ points borderline insomnia, $>10$ points - insomnia. The scoring of the BDI - a 21-item self-report measure of depressive symptoms is as follows: 0-11 points - no depression, 12-26 points - mild depression, 27-49 points - moderate depression, and 50-63 points - severe depression. The SF-36 v. 2 consists of 11 questions and 36 statements (possible answers) assigned to them, which concern self-reported QoL in 8 domains: physical functioning (PF), role physical (RP) - referring to the limitations in usual role activities because of physical health problems, bodily pain (BP), general health (GH), vitality (VT), social functioning (SF), role emotional (RE) - limitations in usual role activities because of emotional problems, and mental health (MH). The final QoL score is the sum of the points obtained for all 8 domains and may range $0-100$ points - the higher the score, the better the QoL.

Statisical analysis was performed using Statistica 13. The level of statistical significance was set as $\mathrm{p} \leq 0.05$. We applied elements of descriptive statistics and statistical inference. We applied the Shapiro-Wilk W test for normality, the chisquare test of independence, ANOVA, the Kruskal-Wallis test by ranks.

TABLE 1. The sociodemographic data of the study sample

\begin{tabular}{|c|c|c|c|c|}
\hline Variable & $\begin{array}{l}\text { Total } \\
\text { n (\%) }\end{array}$ & $\begin{array}{l}\text { Employed } \\
\text { n(\%) }\end{array}$ & $\begin{array}{c}\text { Unemployed } \\
\text { n (\%) }\end{array}$ & $\begin{array}{l}x^{2} \\
p \\
V\end{array}$ \\
\hline $\begin{array}{l}\text { Sex } \\
\text { Women } \\
\text { Men }\end{array}$ & $\begin{array}{l}360(60.30) \\
237(39.70)\end{array}$ & $\begin{array}{l}230(63.89) \\
166(70.04)\end{array}$ & $\begin{array}{c}130(36.11) \\
71(29.96)\end{array}$ & $\begin{array}{l}2.422 \\
0.119\end{array}$ \\
\hline $\begin{array}{l}\text { Age } \\
\text { Up to } 25 \text { years } \\
26-35 \\
36-45 \\
46-55 \\
56 \text { years and more }\end{array}$ & $\begin{array}{l}171(28.64) \\
157(26.3) \\
80(13.40) \\
93(15.58) \\
96(16.08)\end{array}$ & $\begin{array}{c}99(57.90) \\
128(81.53) \\
69(86.25) \\
72(77.42) \\
28(29.17)\end{array}$ & $\begin{array}{l}72(42.10) \\
29(18.47) \\
11(13.75) \\
21(22.58) \\
68(70.83)\end{array}$ & $\begin{array}{c}100.391 \\
\leq \mathbf{0 . 0 0 1} \\
0.410 *\end{array}$ \\
\hline $\begin{array}{l}\text { Marital status } \\
\text { Single } \\
\text { Married } \\
\text { Widowed } \\
\text { Divorced }\end{array}$ & $\begin{array}{c}287(48.07) \\
247(41.37) \\
23(3.85) \\
40(6.70)\end{array}$ & $\begin{array}{c}189(65.85) \\
172(69.64) \\
6(26.09) \\
29(72.50)\end{array}$ & $\begin{array}{l}98(34.15) \\
75(30.36) \\
17(73.91) \\
11(27.50)\end{array}$ & $\begin{array}{l}18.598 \\
\leq 0.001 \\
0.176^{*}\end{array}$ \\
\hline $\begin{array}{l}\text { Education } \\
\text { Primary } \\
\text { Vocational } \\
\text { Secondary } \\
\text { Tertiary }\end{array}$ & $\begin{array}{c}16(2.68) \\
62(10.39) \\
204(34.17) \\
315(52.76)\end{array}$ & $\begin{array}{c}7(43.75) \\
40(64.52) \\
113(55.39) \\
236(74.92)\end{array}$ & $\begin{array}{c}9(56.25) \\
22(35.48) \\
91(44.61) \\
79(25.08)\end{array}$ & $\begin{array}{l}25.081 \\
\leq 0.001 \\
0.204^{*}\end{array}$ \\
\hline $\begin{array}{l}\text { Place of residence } \\
\text { City } \\
\geq 100,000 \\
50-99,999 \\
10-49,999 \\
5000-9,999 \\
\text { Rural areas }\end{array}$ & $\begin{array}{c}408(68.34) \\
239(58.58) \\
73(17.89) \\
68(16.67) \\
30(7.35) \\
187(31.32)\end{array}$ & $\begin{array}{c}289(70.83) \\
186(77.82) \\
36(49.32) \\
46(67.65) \\
22(73.33) \\
106(56.68)\end{array}$ & $\begin{array}{l}119(29.17) \\
53(22.18) \\
37(50.68) \\
22(32.36) \\
8(26.67) \\
81(43.32)\end{array}$ & $\begin{array}{l}32.104 \\
\leq 0.001 \\
0.231^{*}\end{array}$ \\
\hline
\end{tabular}

* $\vee$ - Cramer's $V$ coefficient 
TABLE 2. The socioeconomic data of the study sample

\begin{tabular}{|c|c|c|c|c|}
\hline Variable & $\begin{array}{l}\text { Total } \\
\mathrm{n}(\%)\end{array}$ & $\begin{array}{l}\text { Employed } \\
\text { n (\%) }\end{array}$ & $\begin{array}{l}\text { Unemployed } \\
\qquad \mathrm{n}(\%)\end{array}$ & $\begin{array}{l}x^{2} \\
p \\
v\end{array}$ \\
\hline $\begin{array}{l}\text { Actual profession according to KZiS*** } \\
\text { Technicians and associate professionals } \\
\text { Industry workers and craftsmen } \\
\text { Operators and fitters } \\
\text { Specialists } \\
\text { Service and sales workers } \\
\text { Office workers } \\
\text { Other****}\end{array}$ & $\begin{array}{l}51(13.64) \\
41(10.96) \\
26(6.95) \\
129(34.49) \\
49(13.10) \\
60(16.04) \\
18(4.81)\end{array}$ & $\begin{array}{l}51(13.64) \\
41(10.96) \\
26(6.95) \\
129(34.49) \\
49(13.10) \\
60(16.04) \\
18(4.81)\end{array}$ & & $\begin{array}{l}0.000 \\
1.000 \\
-\end{array}$ \\
\hline $\begin{array}{l}\text { Shift-work } \\
\text { Yes } \\
\text { No } \\
\text { Not provided }\end{array}$ & $\begin{array}{c}201(33.67) \\
385(64.49) \\
11(1.84)\end{array}$ & $\begin{array}{l}137(68.16) \\
259(67.27) \\
-\end{array}$ & $\begin{array}{c}64(31.84) \\
126(32.73) \\
11(100)\end{array}$ & $\begin{array}{c}0.047 \\
0.827 \\
-\end{array}$ \\
\hline $\begin{array}{l}\text { Form of employment***** } \\
\text { Employment contract } \\
\text { yes } \\
\text { no }\end{array}$ & - & $\begin{array}{l}277(69.95) \\
119(30.05)\end{array}$ & - & $\begin{array}{c}47.472 \\
\leq 0.001 \\
-0.336^{* *}\end{array}$ \\
\hline $\begin{array}{l}\text { Fee-for-task agreement } \\
\text { yes } \\
\text { no }\end{array}$ & - & $\begin{array}{c}73(18.43) \\
323(81.57)\end{array}$ & - & $\begin{array}{c}5.134 \\
\mathbf{0 . 0 2 3} \\
-0.110^{* *}\end{array}$ \\
\hline $\begin{array}{l}\text { Contract for a specific task } \\
\text { yes } \\
\text { no }\end{array}$ & - & $\begin{array}{c}5(1.26) \\
391(98.74)\end{array}$ & - & $\begin{array}{c}0.293 \\
0.587 \\
- \\
\end{array}$ \\
\hline $\begin{array}{l}\text { Contract } \\
\text { yes } \\
\text { no }\end{array}$ & - & $\begin{array}{c}20(5.05) \\
376(94.95)\end{array}$ & - & $\begin{array}{c}1.219 \\
0.269 \\
-\end{array}$ \\
\hline $\begin{array}{l}\text { Other } \\
\text { yes } \\
\text { no }\end{array}$ & - & $\begin{array}{c}34(8.61) \\
361(91.39)\end{array}$ & - & $\begin{array}{l}2.155 \\
0.142\end{array}$ \\
\hline $\begin{array}{l}\text { Current source of income } \\
\text { Work } \\
\text { Retirement pension } \\
\text { Disability benefit } \\
\text { Retirement pension + work } \\
\text { Disability benefit + work } \\
\text { Spouse } \\
\text { Parents }\end{array}$ & $\begin{array}{c}384(64.32) \\
53(8.88) \\
23(3.85) \\
5(0.84) \\
8(1.34) \\
37(6.20) \\
87(14.57)\end{array}$ & $\begin{array}{c}367(95.57) \\
- \\
- \\
2(40) \\
7(87.50) \\
4(10.81) \\
16(18.40)\end{array}$ & $\begin{array}{l}17(4.43) \\
53(100) \\
23(100) \\
3(60) \\
1(12.50) \\
33(89.19) \\
71(81.6)\end{array}$ & $\begin{array}{l}416.893 \\
\leq 0.001 \\
0.835^{\star}\end{array}$ \\
\hline $\begin{array}{l}\text { Self-reported financial standing } \\
\text { Very good } \\
\text { Good } \\
\text { Satisfactory } \\
\text { Bad }\end{array}$ & $\begin{array}{c}62(10.39) \\
299(50.08) \\
208(34.84) \\
28(4.69)\end{array}$ & $\begin{array}{c}51(82.26) \\
208(69.57) \\
125(60.10) \\
12(42.86)\end{array}$ & $\begin{array}{l}11(17.74) \\
91(30.43) \\
83(39.90) \\
16(57.14)\end{array}$ & $\begin{array}{l}18.971 \\
\leq 0.001 \\
0.178^{\star}\end{array}$ \\
\hline
\end{tabular}

* V-Cramer's V coefficient; ** Fi - Fi coefficient; *** KZiS - the Polish Classification of Occupations and Specializations for Labor Market Needs; **** For the purposes of statistical analysis, the group "other" included representatives of: authorities and high officials, farmers, gardeners, foresters and fishermen, employees doing unqualified work, armed forces; ${ }^{* * * *}$ The number of responses (409) is not equal to the number of the employed (396), because it was a multiple-choice question. Percentage values refer to the pool of responses

The research was approved by the Bioethical Commission of the Pomeranian Medical University in Szczecin (approval no. KB-0012/63/16).

\section{RESULTS}

Insomnia was evaluated in $106(17.75 \%)$ respondents, including 128 (63.68\%) unemployed and 168 (42.42\%) employed - Table 3.

Insomnia was statistically significantly related to sex $(p=0.006)$ and age $(p \leq 0.001)$ of the participants. It was more common among the women ( $\mathrm{n}=75 ; 20.83 \%)$, those aged over 56 years $(n=26 ; 27.08 \%)$, and those aged up to 25 years (n $=25 ; 14.62 \%$ ) - Table 4 .

There was a statistically significant relationship between insomnia and employment status ( $\mathrm{p} \leq 0.001)$. Insomnia was more common among the unemployed respondents $(n=53$; $26.37 \%$ ), and those performing specialist work ( $\mathrm{n}=12$; $9.30 \%)$. Furthermore, we observed that every 5 th person doing shift work $(n=40 ; 19.9 \%)$ had insomnia, and $1 / 3(n=66$; $32.84 \%$ ) was at risk of insomnia. Sleep problems were also statistically significantly related to contract work for 
TABLE 3. Insomnia among the employed and unemployed individuals

\begin{tabular}{|c|c|c|c|}
\hline \multirow[b]{2}{*}{ Variable } & \multicolumn{3}{|c|}{ The Athens Insomnia Scale (AIS) } \\
\hline & $\begin{array}{c}\text { no insomnia } \\
n(\%)\end{array}$ & $\begin{array}{l}\text { borderline insomnia } \\
\mathrm{n}(\%)\end{array}$ & $\begin{array}{l}\text { insomnia } \\
\mathrm{n}(\%)\end{array}$ \\
\hline Unemployed & $73(36.31)$ & 75 (37.31) & $53(26.37)$ \\
\hline
\end{tabular}

AIS: no insomnia $\leq 5$ points, borderline insomnia 6-10 points, insomnia >10 points

TABLE 4. The relationship between insomnia and sociodemographic data

\begin{tabular}{|c|c|c|c|c|c|c|}
\hline \multirow[b]{2}{*}{ Variable } & \multicolumn{3}{|c|}{ The Athens Insomnia Scale (AIS) } & \multirow[b]{2}{*}{$x^{2}$} & \multirow[b]{2}{*}{$\mathrm{p}$} & \multirow[b]{2}{*}{$\mathbf{V}$} \\
\hline & $\begin{array}{c}\text { no insomnia } \\
n(\%)\end{array}$ & $\begin{array}{c}\text { borderline } \\
\text { insomnia } \\
n(\%)\end{array}$ & $\begin{array}{c}\text { insomnia } \\
\mathrm{n}(\%)\end{array}$ & & & \\
\hline \multicolumn{7}{|l|}{ Sex } \\
\hline Women & $164(45.56)$ & $121(33.61)$ & $75(20.83)$ & 10.000 & 0.006 & 0.129 \\
\hline Men & 137 (57.81) & 69 (29.11) & 31 (13.08) & & & \\
\hline \multicolumn{7}{|l|}{ Age } \\
\hline Up to 25 years & $89(52.05)$ & $57(33.33)$ & $25(14.62)$ & \multirow{5}{*}{28.415} & \multirow{5}{*}{$\leq 0.001$} & \multirow{5}{*}{0.154} \\
\hline $26-35$ & $94(59.87)$ & $42(26.75)$ & $21(13.38)$ & & & \\
\hline $36-45$ & $27(33.75)$ & $36(45)$ & $17(21.25)$ & & & \\
\hline $46-55$ & $55(59.14)$ & $21(22.58)$ & $17(18.28)$ & & & \\
\hline 56 years and more & $36(37.50)$ & $34(35.42)$ & $26(27.08)$ & & & \\
\hline \multicolumn{7}{|l|}{ Marital status } \\
\hline Single & $156(54.35)$ & $91(31.71)$ & $40(13.94)$ & \multirow{3}{*}{11.262} & \multirow{3}{*}{0.080} & \multirow{3}{*}{-} \\
\hline Married & $120(48.58)$ & $78(31.58)$ & $49(19.84)$ & & & \\
\hline Divorced & $19(47.50)$ & $11(27.50)$ & $10(25)$ & & & \\
\hline \multicolumn{7}{|l|}{ Education } \\
\hline Primary & $7(43.75)$ & $6(37.50)$ & $3(18.75)$ & \multirow{4}{*}{3.492} & \multirow{4}{*}{0.745} & \multirow{4}{*}{-} \\
\hline Vocational & $29(46.77)$ & $19(30.65)$ & $14(22.58)$ & & & \\
\hline Secondary & $105(51.47)$ & $59(28.92)$ & $40(19.61)$ & & & \\
\hline Tertiary & $160(50.79)$ & $106(33.65)$ & 49 (15.56) & & & \\
\hline \multicolumn{7}{|l|}{ Place of residence } \\
\hline City & $211(51.72)$ & $128(31.37)$ & $69(16.91)$ & \multirow{6}{*}{20.427} & \multirow{6}{*}{0.008} & \multirow{6}{*}{-} \\
\hline$\geq 100,000$ & $128(53.56)$ & $72(30.12)$ & $39(16.32)$ & & & \\
\hline $50-99,999$ & $23(31.50)$ & $29(39.73)$ & $21(28.77)$ & & & \\
\hline $10-49,999$ & $39(57.35)$ & $22(32.35)$ & $7(10.29)$ & & & \\
\hline $5000-9,999$ & $21(70)$ & $6(20)$ & $3(10)$ & & & \\
\hline Rural areas & $90(48.13)$ & $61(32.62)$ & $36(19.25)$ & & & \\
\hline
\end{tabular}

$V$-Cramer's V coefficient; AIS: no insomnia $\leq 5$ points, borderline insomnia $6-10$ points, insomnia $>10$ points

a specific task $(\mathrm{p}=0.004)$ and temporary work performed by unemployed individuals ( $p=0.042$ ), as well as to the source of income $(p \leq 0.001)$. Insomnia was found in half of the respondents with poor financial standing $(\mathrm{n}=14$; 50\%) - Table 5 .

A statistically significant relationship between insomnia assessed by AIS and depressive symptoms was demonstrated in each of the groups analyzed in this study $(\mathrm{p} \leq 0.001)$ - Table 6.
We checked for statistically significant relationships between insomnia and chronic diseases in particular groups. Table 7 only shows the diseases that were statistically significantly related to insomnia. In the whole study sample, insomnia was statistically significantly related to hypertension $(\mathrm{p} \leq 0.001)$ and other diseases reported by the respondents ( $\mathrm{p} \leq 0.001)$. In the group of employed individuals, insomnia was found in $1 / 4$ of those with hypertension $(n=13 ; 22.41 \%)$, 
TABLE 5. The relationship between insomnia and socioeconomic factors

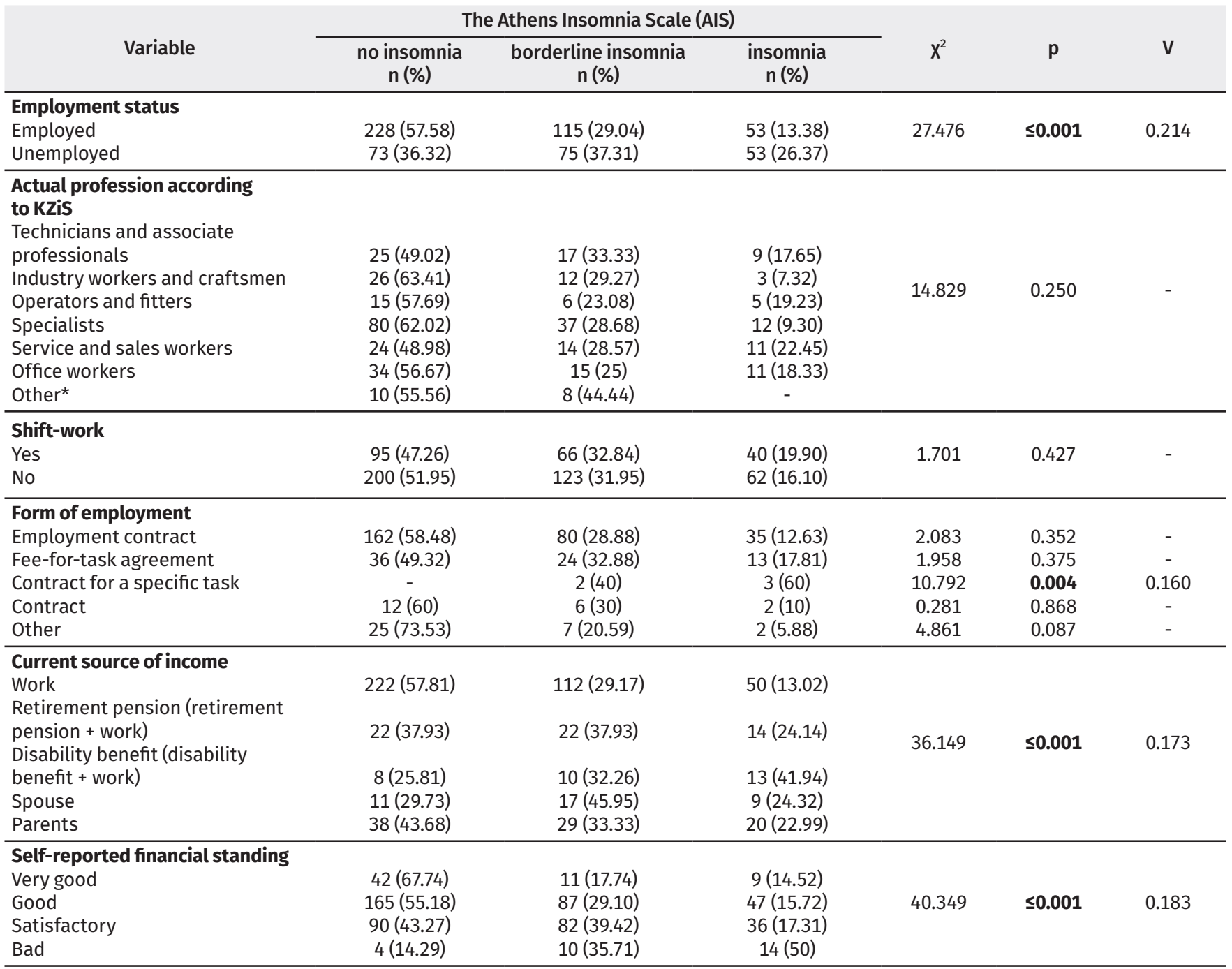

$V$-Cramer's V coefficient; AIS: no insomnia $\leq 5$ points, borderline insomnia $6-10$ points, insomnia $>10$ points; * For the purposes of statistical analysis, the group 'other' included representatives of: authorities and high officials, farmers, gardeners, foresters and fishermen, employees doing unqualified work, armed forces

and the majority of those with atherosclerosis $(n=2 ; 66.67 \%)$ and hyperthyroidism $(n=8 ; 32 \%)$. In the group of unemployed individuals, a significant relationship was only confirmed between insomnia and other diseases reported by the respondents $(\mathrm{p}=0.037)$.

We assessed the link between insomnia and QoL in all groups. In the whole study sample, the highest scores were obtained for QoL in the physical PF domain: 85.16 \pm 20.16 . The employed individuals scored higher in all QoL domains compared with the unemployed ones. The greatest differences between the employed and the unemployed respondents were observed in the domains of SF (those employed scored 75.41 \pm 22.77 on average, and the unemployed: $65.17 \pm 24.71$ ), and $\mathrm{MH}$ (the employed individuals scored $70.2 \pm 20.27$, and the unemployed: $60.66 \pm 21.23)$. The employed participants obtained the lowest QoL scores in the domains of GH (59.67 \pm 20.77$)$ and VT (62.5 \pm 22.5$)$. Similarly, the unemployed individuals had the lowest QoL scores for GH (52.41 \pm 21.58$)$ and VT $(54.4 \pm 21.41)$ 
TABLE 6. The relationship between insomnia and depressive symptoms

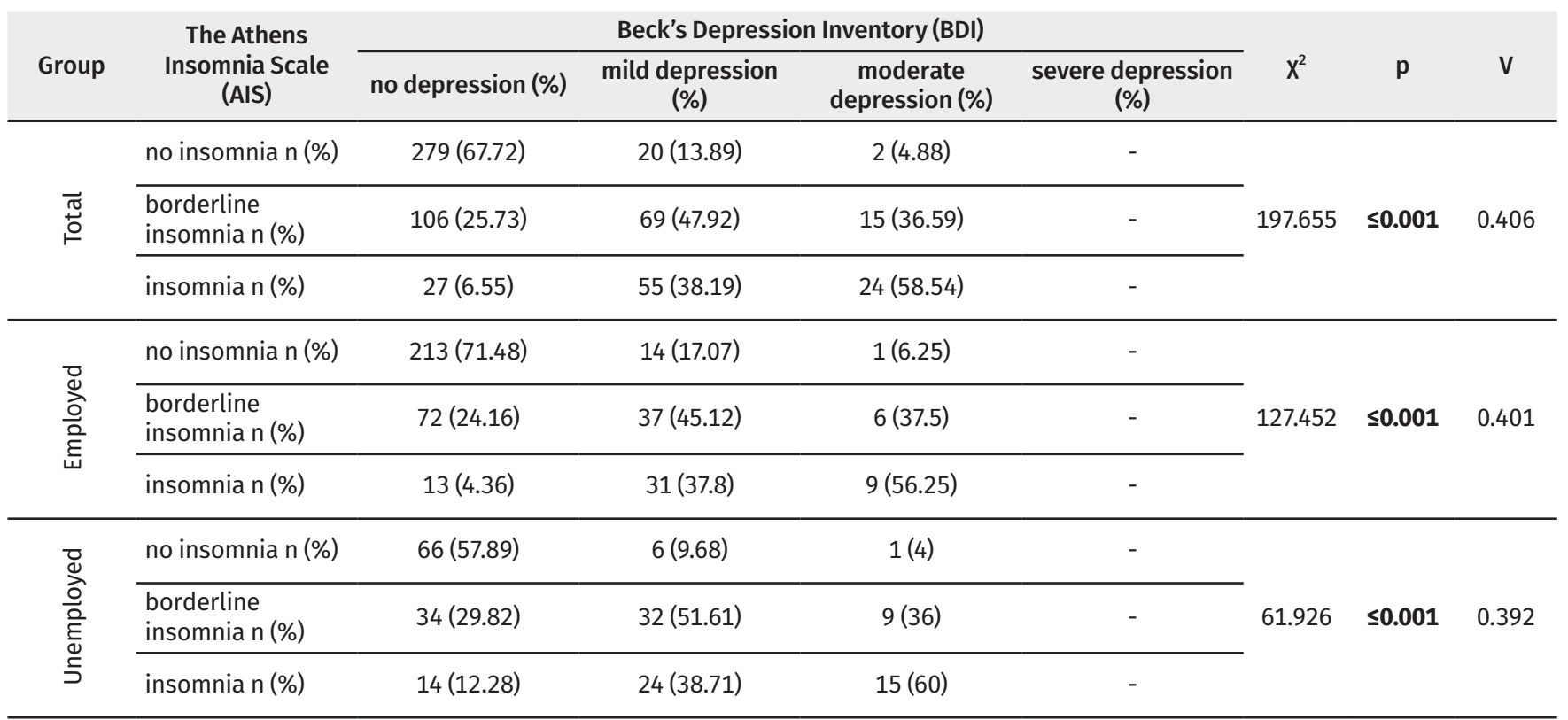

$\checkmark$ - Cramer's V coefficient; AIS: no insomnia $\leq 5$ points, borderline insomnia 6-10 points, insomnia >10 points; BDI: no depression o-11 points, mild depression 12-26 points, moderate depression 27-49 points, severe depression 50-63 points

TABLE 7. The relationship between insomnia and chronic diseases

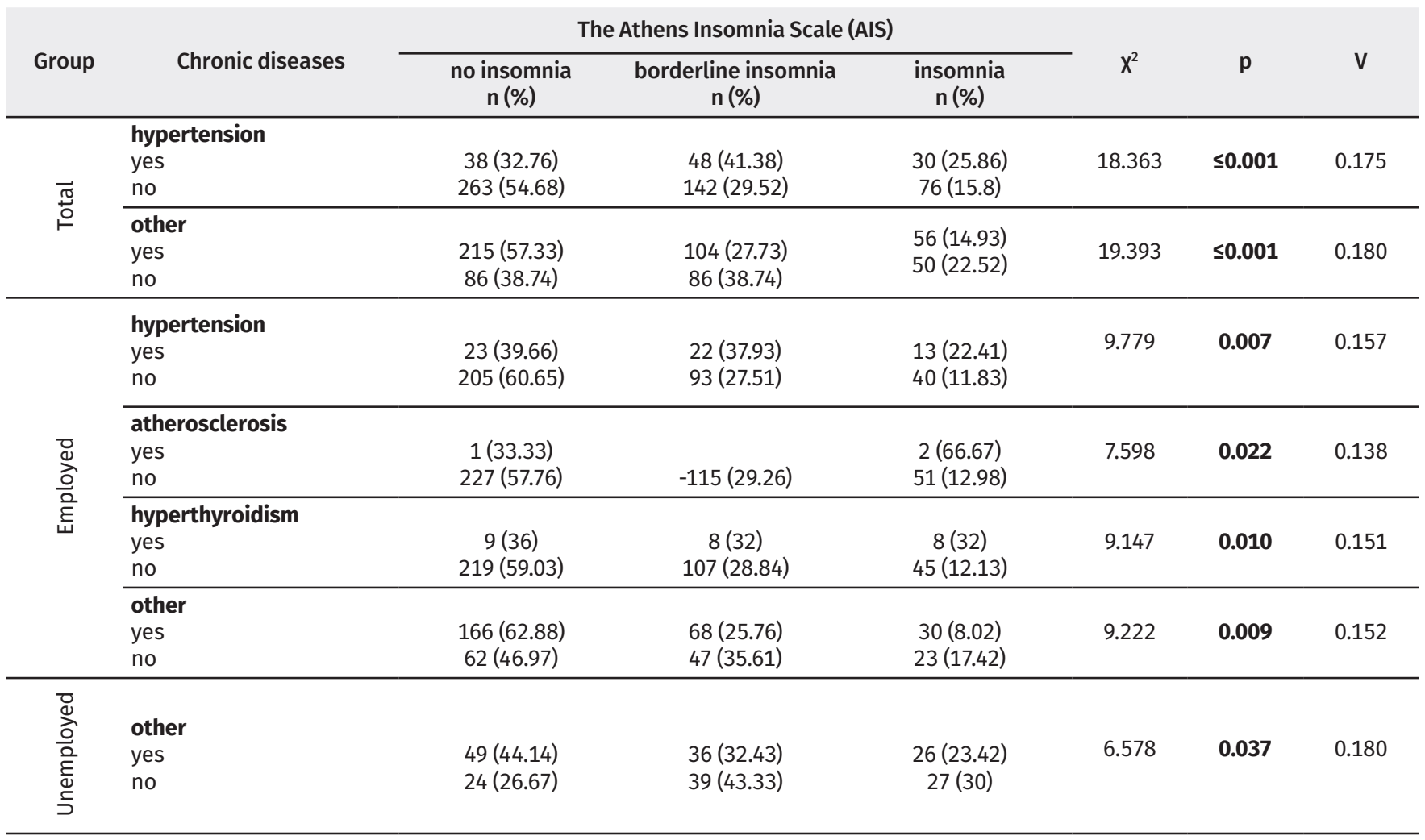

V-Cramer's V coefficient; AIS: no insomnia $\leq 5$ points, borderline insomnia 6-10 points, insomnia >10 points 
TABLE 8. Quality of life according to the Short Form 36 Health Survey domains

\begin{tabular}{|c|c|c|c|c|c|c|c|c|c|}
\hline \multirow{2}{*}{ SF-36 } & \multicolumn{3}{|c|}{ Total } & \multicolumn{3}{|c|}{ Employed } & \multicolumn{3}{|c|}{ Unemployed } \\
\hline & $X \pm S D$ & $\begin{array}{c}\mathrm{Cl}-95 \% \\
+95 \%\end{array}$ & min.-max. & $\mathrm{X} \pm \mathrm{SD}$ & $\begin{array}{c}\mathrm{Cl}-95 \% \\
+95 \%\end{array}$ & $\min .-\max$ & $\mathrm{X} \pm \mathrm{SD}$ & $\begin{array}{c}\mathrm{Cl}-95 \% \\
+95 \%\end{array}$ & min.-max. \\
\hline $\mathrm{BP}$ & $73.71 \pm 24.59$ & $23.27-26.07$ & $0-100$ & $75.51 \pm 24.08$ & $22.51-25.88$ & $0-100$ & $70.15 \pm 25.27$ & $23.01-28.01$ & $0-100$ \\
\hline $\mathrm{GH}$ & $57.22 \pm 21.31$ & $20.16-22.59$ & $0-100$ & $59.67 \pm 20.77$ & $19.42-22.33$ & $5-100$ & $52.41 \pm 21.58$ & $19.65-23.92$ & $0-100$ \\
\hline SF & $71.96 \pm 23.92$ & $22.63-25.36$ & $0-100$ & $75.41 \pm 22.77$ & $21.29-24.48$ & $12.5-100$ & $65.17 \pm 24.71$ & $22.51-27.4$ & $0-100$ \\
\hline PF & $85.16 \pm 20.16$ & $19.08-21.37$ & $0-100$ & $87.06 \pm 18.63$ & $17.42-20.03$ & $5-100$ & $81.42 \pm 22.46$ & $20.46-24.9$ & $0-100$ \\
\hline $\mathrm{RP}$ & $77.29 \pm 24.39$ & $23.08-25.86$ & $0-100$ & $79.81 \pm 23.58$ & $22.04-25.35$ & $0-100$ & $72.33 \pm 25.25$ & $23-27.99$ & $0-100$ \\
\hline $\mathrm{MH}$ & $66.98 \pm 21.07$ & $19.94-22.34$ & $0-100$ & $70.2 \pm 20.27$ & $18.95-21.79$ & $12-100$ & $60.66 \pm 21.23$ & $19.33-23.53$ & $0-100$ \\
\hline QoL & $71.31 \pm 17.15$ & $16.22-18.18$ & 21.41-100 & $73.92 \pm 16.51$ & $15.43-17.74$ & $21.4-100$ & $66.17 \pm 17.27$ & $15.73-19.15$ & $21.69-98.13$ \\
\hline $\mathrm{p}$ & & $\leq 0.001$ & & & $\leq 0.001$ & & & $\leq 0.001$ & \\
\hline
\end{tabular}

BP - bodily pain; GH - general health; VT - vitality; SF - social functioning; PF - physical functioning; RP - role physical; RE - role emotional; ME - mental health; QoL - quality of life

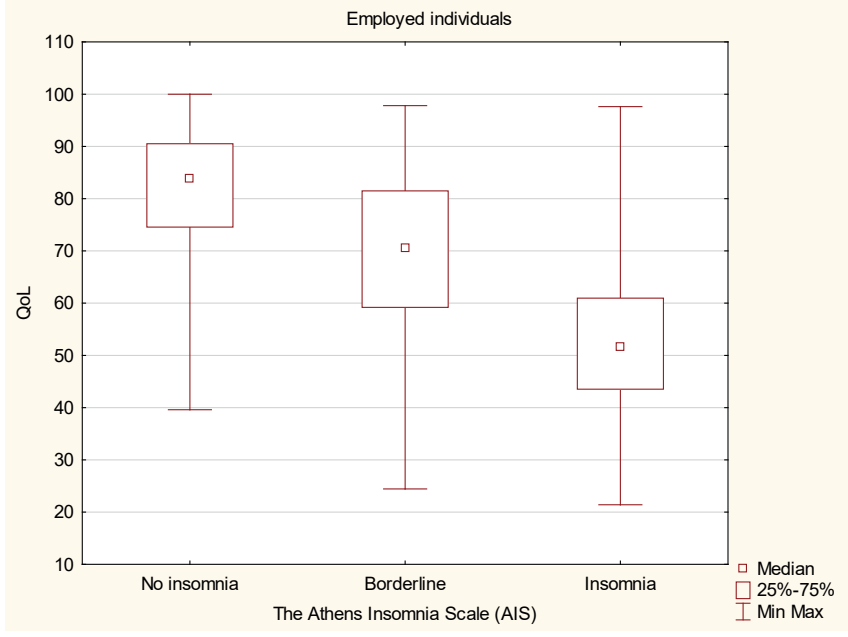

FIGURE 1. The relationship between insomnia and general quality of life scores in the group of employed participants

domains. The employed respondents had higher general QoL scores (72.92 \pm 16.51$)$ - Table 8 . There was a significant relationship ( $\mathrm{p} \leq \mathrm{0.001}$ ) between insomnia and general QoL scores both in the employed (Fig. 1) and the unemployed participants (Fig. 2). Insomnia significantly reduced QoL.

\section{DISCUSSION}

The incidence of insomnia depends on many factors, including diagnostic criteria. Our results demonstrated this condition in $17.75 \%$ of the participants. Based on their study of over 50,000 respondents, Sivertsen et al. reported insomnia in $13.5 \%$ of

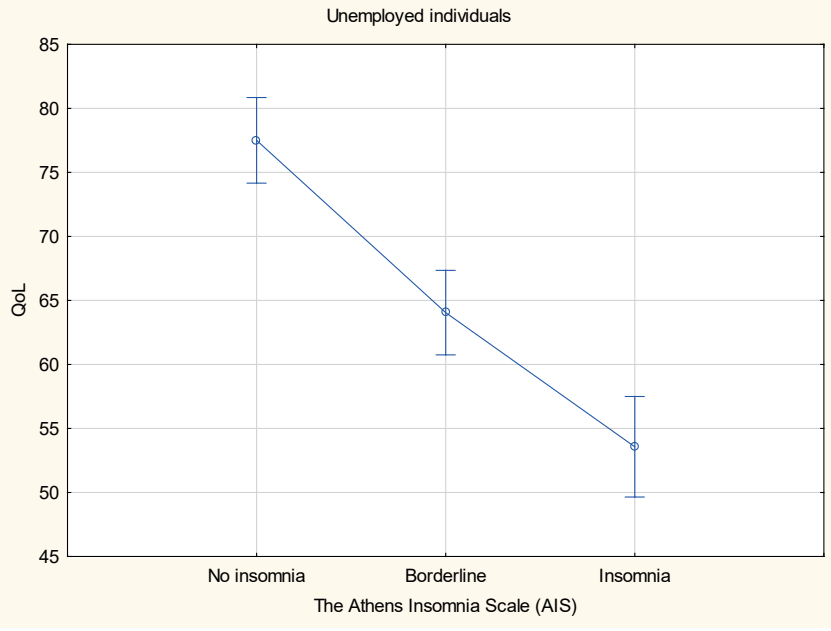

FIGURE 2. The relationship between insomnia and general quality of life scores in the group of unemployed participants

those surveyed, the majority of whom were women [29]. Cai et al. found insomnia in $19.2 \%$ of their study sample [30], and Ohayon informed that it may affect $4-48 \%$ of the populations of developed countries [7].

In our study, insomnia was noted in $13.38 \%$ of the employed individuals, and $26.37 \%$ of those unemployed, which indicates that the latter were more often afflicted. Similarly, according to Benbir et al. insomnia was only occasionally diagnosed in the respondents receiving a regular salary (i.e. employed on a permanent basis), and it was most common among those unemployed and housewives [31]. Vancampfort et al., who analyzed the impact of sedentary lifestyles and jobs on the occurrence of sleep disorders in over 40,000 respondents, confirmed 
that people living sedentary lives were at 1.75 higher risk (95\% CI $=1.21-2.40)$ of sleep disorders than those with sedentary behavior only $4 \mathrm{~h}$ per day on average [32].

Our results revealed the connection between insomnia and sex - insomnia was more common in women (20.83\%). Other authors reported comparable findings. The study based on a nationwide survey of the Polish citizens, conducted by Nowicki et al., demonstrated insomnia in nearly $60 \%$ of the women and $40 \%$ of the men [33]. Uhling et al., who analyzed 93,860 respondents in Norway, observed insomnia in $9 \%$ of the women and $5.5 \%$ of the men [12]. Also a Finnish study of 5,500 individuals confirmed that the women (14\%) suffered from insomnia more often than the men (10\%) [9]. The relationship between insomnia and female sex can be associated with the endocrine system, and especially changes in the levels of hormones, such as estrogen and progesterone, which substantially influence the sleep-waking cycle [11, 34, 35].

In our study insomnia was more common among younger individuals (up to 25 years of age) and those over 56 years of age, while according to Nowicki et al. insomnia was more widespread among 60-79 year olds than those aged 18-59 years [33]. The process of aging can involve changes in the frequency of sleep disorders, and lower quality of sleep [36, 37].

Our study revealed the association between insomnia and a contract for a specific task - the majority of the participants having such a form of employment suffered from insomnia, as the lack of permanent job status can cause stress and, as a consequence, lead to health problems (including insomnia). Żołnierczyk-Zreda's review of research concerning the type of an employment contract and its impact on health and professional functioning shows that the lack of an open-ended employment contract negatively affects mental and physical health, consequently causing a decline in sleep quality [27]. In our investigation, insomnia was mostly noted in the employed individuals and those supported by parents. Such results may have been associated with the structure of our study sample, which mostly consisted of students aged up to 25 years. Similar observations were made by Średniawa et al., who analyzed 264 students, demonstrating insomnia in $19.7 \%$ of them [38]. A significant relationship has been documented between insomnia and retirement pension, which may be associated with age [39]. Studies concerning the link between retirement pension and sleep disorders (including insomnia), on the other hand, show that people suffering from sleep problems are more likely to retire early $[40,41]$.

In our investigation, insomnia was substantially related to depressive symptoms. As stated by Benbir et al., as many as $13 \%$ of the respondents with insomnia suffered from depressive symptoms and other mental problems [31]. The meta-analysis of 13 studies, performed by Hertenstein et al., showed clearly that insomnia is the best predictor of depressive symptoms (OR 2.83, CI 1.55-5.17) and anxiety (OR 3.23, CI 1.52-6.85) [42].

We observed the connection between insomnia and hypertension in the whole study sample $(\mathrm{p} \leq 0.001)$, and in the employed individuals $(\mathrm{p}=0.007)$. In the study of Vgontzas et al., insomnia entailed a higher risk of hypertension.
Concomitance of insomnia and sleep duration below $5 \mathrm{~h}$ was a factor increasing the risk of hypertension by about $500 \%$ $(\mathrm{OR}=5.12,95 \% \mathrm{CI} 2.2-11.8)$ compared with the respondents having no insomnia and sleeping more than $6 \mathrm{~h}$ per night [43]. In numerous studies carried out in recent years, people with insomnia were at a $15-41 \%$ greater risk of hypertension $[44,45$, 46], and even death from heart disease [47] than those without sleep problems.

In the group of employed individuals in our study, insomnia was related to hyperthyroidism. The respondents with thyroid problems (both hyperthyroidism and hypothyroidism) had problems falling asleep, woke up too early and could not fall asleep again. Taking thyrotropin-releasing hormone (TRH) can change the sleep pattern, causing daytime sleepiness and the shortening of sleep duration [48].

Insomnia noticeably decreased QoL in all groups analyzed in our study. Similar conclusions were drawn by Léger et al., who found that the more severe the insomnia, the lower the QoL in all domains [24]. In a study of over 100,000 respondents, conducted by Scalo et al., the occurrence of insomnia was accompanied by a decline in QoL in all domains, irrespective of taking hypnotic drugs [49]. Darchia et al., who analyzed 20-60 year-olds in Georgia, informed that worse quality of sleep considerably reduced QoL in all domains. What is more, these authors provided evidence for a strong influence of insomnia on the QoL mental health component [50].

\section{CONCLUSIONS}

1. Insomnia was more common in unemployed individuals. Important determinants were female sex, age, type of an employment contract, source of income, and self-reported financial standing.

2. Insomnia was more common in the respondents with hypertension, irrespective of their employment status. Therefore, primary care physicians should use the AIS as part of screening among chronically ill patients.

3. Insomnia was accompanied by depressive symptoms in all groups analyzed in this study, irrespective of their employment status.

4. Insomnia is a serious public and mental health problem. The AIS should be used as part of workers' periodic health examinations, since ignoring the problem of insomnia decreases QoL.

\section{REFERENCES}

1. Littlehales N. Śpij dobrze. Warszawa: Wydawnictwo Agora; 2017.

2. American Psychiatric Association. Diagnostic and Statistical Manual of Mental Disorders. 5th ed. Washington: American Psychiatric Association; 2013.

3. Skalski M, Fornal M, Szelenberger W. Rodzinne występowanie bezsenności nieorganicznej. Sen 2006;6(1):1-7.

4. Prusiński A. Bezsenność i inne zaburzenia snu. Wyd. 2. Warszawa: Wydawnictwo Lekarskie PZWL; 2007. p. 12-43. 
5. Yaffe K, Falvey CM, Hoang T. Connections between sleep and cognition in older adults. Lancet Neurol 2014;13(10):1017-28.

6. Paunio T, Korhonen T, Hublin C, Partinen M, Koskenvuo K, Koskenvuo M et al. Poor sleep predicts symptoms of depression and disability retirement due to depression. J Affect Disord 2015;172:381-9.

7. Ohayon MM. Epidemiology of insomnia: what we know and what we still need to learn. Sleep Med Rev 2002;6(2):97-111.

8. Grandner MA, Patel NP, Gehrman PR, Xie D, Sha D, Weaver T, et al. Who gets the best sleep? Ethnic and socioeconomic factors related to sleep complaints. Sleep Med 2010;11(5):470-8.

9. Lallukka T, Sares-Jäske L, Kronholm E, Sääksjärvi K, Lundqvist A, Partonen T, et al. Sociodemographic and socioeconomic differences in sleep duration and insomnia-related symptoms in Finnish adults. BMC Public Health 2012;12:565.

10. Zhang HS, Li Y, Mo HY, Qiu DX, Zhao J, Luo JL, et al. A community-based cross-sectional study of sleep quality in middle-aged and older adults. Qual Life Res 2017;26(4):923-33.

11. Madrid-Valero JJ, Martínez-Selva JM, Ribeiro do Couto B, Sánchez-Romera JF, Ordoñana JR. Age and gender effects on the prevalence of poor sleep quality in the adult population. Gac Sanit 2017;31(1):18-22.

12. Uhlig BL, Sand T, Odegård SS, Hagen K. Prevalence and associated factors of DSM-V insomnia in Norway: the Nord-Trøndelag Health Study (HUNT 3). Sleep Med 2014;15(6):708-13.

13. Andreeva VA, Torres MJ, Druesne-Pecollo N, Léger D, Gonzalez P, Bayon $\mathrm{V}$, et al. Sex-specific associations of different anthropometric indices with acute and chronic insomnia. Eur J Public Health 2017;27(6):1026-31.

14. Palm A, Janson C, Lindberg $E$. The impact of obesity and weight gain on development of sleep problems in a population-based sample. Sleep Med 2015;16(5):593-7.

15. Assari S, Moghani Lankarani M, Kazemi Saleh D, Ahmadi K. Gender modifies the effects of education and income on sleep quality of the patients with coronary artery disease. Int Cardiovasc Res J 2013;7(4):141-6.

16. Wojtas A, Ciszewski S. Epidemiologia bezsenności. Psychiatria 2011;8(3):79-83.

17. Bruno RM, Palagini L, Gemignani A, Virdis A, Di Giulio A, Ghiadoni $\mathrm{L}$, et al. Poor sleep quality and resistant hypertension. Sleep Med 2013;14(11):1157-63.

18. Pracka D, Pracki T. Chronobiologia rytmu sen-czuwanie. Sen 2002;2 Suppl A:A7-A12.

19. Maury E, Ramsey KM, Bass J. Circadian rhythms and metabolic syndrome: from experimental genetics to human disease. Circ Res 2010;106(3):447-62.

20. Laposky AD, Bass J, Kohsaka A, Turek FW. Sleep and circadian rhy thms: key copmonents in the regulation of energy metabolism. FEBS Lett 2008;582(1):142-51.

21. Levenson JC, Benca RM, Rumble ME. Sleep related cognitions in individuals with symptoms of insomnia and depression. J Clin Sleep Med 2015;11(8):847-54.

22. Baglioni C, Battagliese G, Feige B, Spiegelhalder K, Nissen C, Voderholzer U, et al. Insomnia as a predictor of depression: a meta-analytic evaluation of longitudinal epidemiological studies. J Affect Disord 2011;135(1-3):10-9.

23. Heitzman J. Zaburzenia snu - przyczyna czy skutek depresji? Psychiatr Pol 2009;43(5):499-511.

24. Léger D, Scheuermaier K, Philip P, Paillard M, Guilleminault C. SF-36: evaluation of quality of life in severe and mild insomniacs compared with good sleepers. Psychosom Med 2001;63(1):49-55.

25. Kang MY, Kwon HJ, Choi KH, Kang CW, Kim H. The relationship between shift work and mental health among electronics workers in South Korea: A cross-sectional study. PLoS One 2017;12(11):e0188019.

26. Virtanen M, Kivimäki M, Joensuu M, Virtanen P, Elovainio M, Vahtera J. Temporary employment and health: A review. Int J Epidemiol 2005;34(3):610-22.

27. Żołnierczyk-Zreda D. Rodzaj umowy o pracę a zdrowie i funkcjonowanie zawodowe pracowników - przegląd badań. Med Pr 2015;66(4):565-73.

28. Heponiemi T, Kouvonen A, Sinervo T, Elovainio M. Do psychosocial factors moderate the association of fixed-term employment with work interference with family and sleeping problems in registered nurses: a cross sectional questionnaire survey. Int J Nurs Stud 2010;47(9):1096-104.
29. Sivertsen B, Krokstad S, Øverland S, Mykletun A. The epidemiology of insomnia: associations with physical and mental health. The HUNT-2 study. J Psychosom Res 2009;67(2):109-16.

30. Cai GH, Theorell-Haglöw J, Janson C, Svartengren M, Elmståhl S, Lind L, et al. Insomnia symptoms and sleep duration and their combined effects in relation to associations with obesity and central obesity. Sleep Med 2018;46:81-7.

31. Benbir G, Demir AU, Aksu M, Ardic S, Firat H, Itil O, et al. Prevalence of insomnia and its clinical correlates in a general population in Turkey. Psychiatry Clin Neurosci 2015;69(9):543-52.

32. Vancampfort D, Stubbs B, Firth J, Hagemann N, Myin-Germeys I, Rintala A, et al. Sedentary behaviour and sleep problems among 42,489 community-dwelling adults in six low- and middle-income countries. J Sleep Res 2018;27(6):e12714. doi: 10.1111/jsr.12714.

33. Nowicki Z, Grabowski K, Cubała WJ, Nowicka-Sauer K, Zdrojewski T, Rutkowski M, et al. Rozpowszechnienie subiektywnej bezsenności w populacji polskiej. Psychiatr Pol 2016;50(1):165-73.

34. Xu M, Bélanger L, Ivers H, Guay B, Zhang J, Morin CM. Comparison of subjective and objective sleep quality in menopausal and non-menopausal women with insomnia. Sleep Med 2011;12(1):65-9.

35. Krupka-Matuszczyk I. Zaburzenia snu u kobiet. Sen 2008;8(2):73-7.

36. Kim H, Suh S, Cho ER, Yang HC, Yun CH, Thomas RJ, et al. Longitudinal course of insomnia: Age-related differences in subjective sleepiness and vigilance performance in a population-based sample. J Psychosom Res 2013;75(6):532-8.

37. Duffy JF, Willson HJ, Wang W, Czeisler CA. Healthy older adults better tolerate sleep deprivation than young adults. J Am Geriatr Soc 2009;57(7):1245-51.

38. Średniawa A, Drwiła D, Krotos A, Wojtaś D, Kostecka N, Tomasik T. Insomnia and the level of stress among students in Krakow, Poland. Trends Psychiatry Psychother 2019. pii: S2237-60892019005001102.

39. Wong WS, Fielding R. Prevalence of insomnia among Chinese adults in Hong Kong: a population-based study. J Sleep Res 2011;20(1 Pt 1):117-26.

40. Hale L, Singer L, Barnet JH, Peppard PE, Hagen EW. Associations between midlife insomnia symptoms and earlier retirement. Sleep Health 2017;3(3):170-7.

41. Sivertsen B, Øverland S, Pallesen S, Bjorvatn B, Nordhus IH, Maeland JG, et al. Insomnia and long sleep duration are risk factors for later work disability. The Hordaland Health Study. J Sleep Res 2009;18(1):122-8.

42. Hertenstein E, Feige B, Gmeiner T, Kienzler C, Spiegelhalder K, Johann A, et al. Insomnia as a predictor of mental disorders: A systematic review and meta-analysis. Sleep Med Rev 2019;43:96-105.

43. Vgontzas AN, Liao D, Bixler EO, Chrousos GP, Vela-Bueno A. Insomnia with objective short sleep duration is associated with a high risk for hypertension. Sleep 2009;32(4):491-7.

44. Wang YM, Song M, Wang R, Shi L, He J, Fan TT, et al. Insomnia and multimorbidity in the community elderly in China. J Clin Sleep Med 2017;13(4):591-7.

45. Clark AJ, Salo P, Lange T, Jennum P, Virtanen M, Pentti J, et al. Onset of impaired sleep and cardiovascular disease risk factors: A longitudinal study. Sleep 2016;39(9):1709-18.

46. Lin CL, Liu TC, Lin FH, Chung CH, Chien WC. Association between sleep disorders and hypertension in Taiwan: a nationwide population-based retrospective cohort study. J Hum Hypertens 2017;31(3):220-4.

47. Parthasarathy S, Vasquez MM, Halonen M, Bootzin R, Quan SF, Martinez FD, et al. Persistent insomnia is associated with mortality risk. Am J Med 2015;128(3):268-75.e2.

48. Xia L, Chen GH, Li ZH, Jiang S, Shen J. Alterations in hypothalamuspituitary-adrenal/thyroid axes and gonadotropin-releasing hormone in the patients with primary insomnia: a clinical research. PLoS One 2013;8(8):e71065.

49. Scalo J, Desai P, Rascati K. Insomnia, hypnotic use, and health-related quality of life in a nationally representative sample. Qual Life Res 2015;24(5):1223-33.

50. Darchia N, Oniani N, Sakhelashvili I, Supatashvili M, Basishvili T, Eliozishvili M, et al. Relationship between sleep disorders and health related quality of life - Results from the Georgia SOMNUS Study. Int J Environ Res Public Health 2018;15(8):1588. 